\title{
S5ynthesis
}

International Scientific Conference of IT and Business-Related Research

\section{THE USE OF THE INTERNET IN DIRECT MARKETING: ADVANTAGES, RESULTS AND LIMITATIONS}

\section{PRIMENA INTERNETA U DIREKTNOM MARKETINGU: PREDNOSTI, REZULTATI I ORGANIČENJA}

\author{
Vladimir Radivojević ${ }^{1}$, Tanja Stanišić ${ }^{2}$ \\ ${ }^{1}$ Ministry of Defense of the Republic of Serbia, Belgrade, Serbia \\ ${ }^{2}$ University of Niš, Faculty of Mathematics and Science, Niš, Serbia
}

\begin{abstract}
:
Internet technology has led to fundamental changes in the communication sphere over the last decade. Its application is particularly important in the process of interactive communication with consumers. The pursuit of self-preservation and improvement of business competitiveness in the globalization era highlights the necessity to create more satisfied and loyal customers. A crucial task of the company in that process is to find the appropriate combination of communication forms that will enable efficient and effective transfer of the appropriate marketing messages to the target market. The research was conducted with the primary aim to indicate causes, describe typical features and tendencies in development of the Internet as a modern marketing media. The research was conducted by using descriptive statistics, hypotheticaldeductive method and comparative analysis. The results indicate numerous benefits of Internet usage in interactive communication as a backbone of modern business, as well as significant issues related to customer privacy protection.
\end{abstract}

\section{Key words:}

Internet, direct marketing, consumers, privacy protection.

\section{INTRODUCTION}

Strong growth of the Internet and computer technology had an impact on all aspects of modern life and business. The technological and information revolution exerted the most striking influence in the field of marketing communication. A new form of communication is characterized by turning the company from the mass media and standardized messages to new media with personalized messages. In its very intensive development, Internet has become an important direct marketing medium and an essential factor in business which transforms local market into national, and national market into global.

The increasing complexity and unpredictability of the audience, as well as the strengthening of global competition, requires from the companies to collect reliable, precise and individualized data and information on the existing and potential customer, in order to be able to create adequate messages and thus gain advantage over competitors. Such trends have created the need to create specific messages directed towards small segments or individual customers.

Direct marketing is one of the most dynamic areas of marketing. Under the influence of technological and IT development, direct marketing was changing its tools during its evolution. Practice has shown that the Internet is the most famous and most effective tool in interactive communication with customers.

\section{Apstrakt:}

Internet tehnologija dovela je do fundamentalnih promena u sferi komuniciranja u protekloj deceniji. Njegova primena posebno je važna u procesu interaktivne komunikacije sa potrošačima. Potreba za samoodržanjem i unapređenjem poslovne konkurentnosti u eri globalizacije naglašava potrebu za stvaranjem zadovoljnih i lojalnih potrošača. Glavni zadatak kompanija u tom procesu jeste da pronađu odgovarajuću kombinaciju komunikacionih oblika koji će omogućiti efikasan i efektivan prenos odgovarajućih marketinških poruka ka ciljnom tržištu. Istraživanje je sprovedeno sa osnovnim ciljem da ukaže na uzroke, opišu karakteristike kao i tendencije u razvoju interneta kao modernog medija koji se koristi u marketingu. Ovo istraživanje sprovedeno je korišćenjem deskriptivne statistike, hipotetičko-deduktivne metode i komparativne analize. Rezultati istraživanja ukazuju na brojne prednosti korišćenja interneta u interaktivnoj komunikaciji, koja predstavlja okosnicu modernog poslovanja, ali i na značajne probleme u domenu zaštite privatnosti potrošača.

\section{Ključne reči:}

internet, direktni marketing, potrošači, zaštita privatnosti.

In the paper with this scope and structure is not possible to describe all the significant features of the Internet as a modern communication media. The purpose of this paper is to point out the significant advantages of the Internet and the basic differences between the Internet and mass media, as well as to examine the key issues in the consumer privacy protection in process of interactive communication.

\section{INTERNET- ITS ORIGINS, TRENDS AND GROWTH}

The Internet is the newest and youngest medium, which has been used in this form for more than 20 years. The emergence of the Internet is related to a joint project between the US military and several research organizations in 1969. Open access to the Internet has revolutionized the way individuals communicate and collaborate, entrepreneurs and corporations conduct business, and governments and citizens interact. At the same time, the Internet has established a revolutionary open model for its own development and governance, encompassing all stakeholders.

Business entities started taking an interest in the Internet in the early 90s. Internet giants such as Yahoo and Amazon launched their online platforms in the mid-1990s amid a wave of new search portals, including Alta Vista, Excite and Infoseek. Google was launched in 1998, taking search to a new level of accuracy and convenience. Other commercial websites, such as 
the auction site eBay, began to dominate the web, solidifying the interactive and global commercial potential of the Internet (Jones et al, 2011). Then, the Internet begins to develop rapidly.

The global proportion of people using the Internet has risen at a compound annual growth rate of $12 \%$ in the period 2008 2012 , reaching a level of $37.9 \%$ of the global population in 2013. The increase in the usage is particularly evident in those regions that had lower levels of Internet usage in 2008, with the comparable growth rates for the period in sub-Saharan Africa and emerging Asia-Pacific exceeding 20\% (Internet Society - Global Internet Report, 2014).

There are more than 3 billion Internet users worldwide today. ${ }^{1}$ This statistic shows that the Internet occupies an important role in all areas of human activity, from the economy, education and science to culture, sports and other segments. This is the reason why "Internet is for everyone" represents the vision of many countries and humanitarian organizations.

Although the Internet is held together by a global set of standards, Global Internet Report 2014 (Internet Society) has shown that there are divisions in the user experience between countries. Furthermore, in spite of the striking, once unimaginable, growth in Internet adoption and usage, the majority of the world population is still not online.

As we can see in Figure 1, the progress towards the vision "Internet is for everyone" is proceeding quickly around the world, as access continues to grow at a significant pace. However, much development remains to be done to bring the economic and social benefits of the Internet to everyone. Furthermore, those who are online are experiencing significant variations in their user experience.

According to Global Internet Report 2014 (Internet Society), for non-Internet users, sitting on the other side of the so-called digital divide, the Internet access is clearly a critical component. With the advent of mobile broadband, which can be rolled out faster and at lower cost than fixed broadband, access is no longer as critical an issue. Nonetheless, affordability remains a significant roadblock. However, the average cost of broadband access in many countries is still too high, and is even greater than the average income of the citizens in some countries.

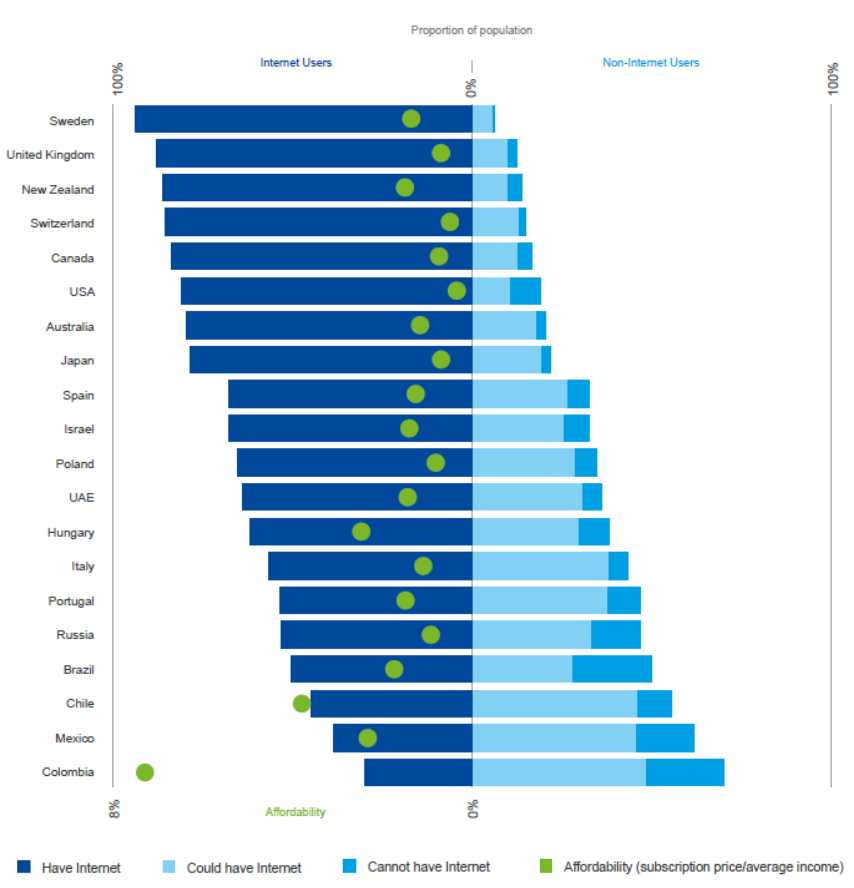

Figure 1. Population of the Internet users and non-users Source: Internet Society - Global Internet Report 2014

13.094 .875 .300 Internet users worldwide

(source: www.internetlivestats.com)

\section{INTERNET AS A MEDIUM OF INTERACTIVE COMMUNICATION}

Compared to other media, the Internet is undoubtedly the most cost-effective medium in interactive communication with consumers. For this reason, it is the simplest, and sometimes the only way to promote small businesses, which are unable to allocate significant funds for advertising.

However, it should not be seen only as a form which reduces advertising costs, but as a development medium that combines two important services: e-mail and website. By combining these services, the Internet provides many advantages in interactive communication with consumers.

The main advantage of e-mail marketing is primarily reflected in the fact that it represents the so-called private media and enables direct contact with the consumer. However, due to technical (graphic and multimedia) limitations of e-mail, its great assistance is adequate website. Conversely, the website cannot provide the possibility of interactive communication with customers. Web and e-mail services allow endless opportunities related to teaching potential customers about the product or service, by promoting new products, affirmative action, conducting discussions on a topic that is in the company's interest (Radivojević \& Krstić, 2012). With the low costs, it is possible to present a lot of information, graphics and images to customers. Thereby, the entire contents can be fully adjusted to their requirements.

Unlike mass media, space, time and costs are not limiting determinants in communicating with customers via the Internet. It provides comfortable position of firm in the process of designing and delivering messages. Advantages in using the Internet, particularly the website as its most popular services in interactive communication activities, are manifold. Some of them are as follows (Đukić, 2007):

- Target focus - the main advantage of the web is the ability to direct promotional efforts towards a specific group of individuals with a minimum loss of time and place;

- Interactive capabilities - lead to the greater interest of the audience, deepen communication and create trust and commitment;

- The constant availability of information - the audience may at any time access to product information, sales conditions and other aspects of transaction;

- Efficient transfer of information - minimum losses and costs;

- Flexibility - the Internet provides a greater ability to adapt offer in direct communication;

- Comfort - integrating communications and transactions allows direct purchasing products and electronic transfer of money;

- Creativity - designing product presentation with combined content - text, animation, sound, graphics and video makes it attractive to visitors, which increases their desire for repeat visits;

- Lower costs - it allows zero incremental costs and access to the entire global market.

Using the website, unlike other media, involves initiating contact by the consumer. This clearly points to a completely different approach to the process of creating messages that will be transmitted to the target market. 


\begin{tabular}{|c|c|}
\hline $\begin{array}{c}\text { Marketing communication via } \\
\text { Internet }\end{array}$ & $\begin{array}{c}\text { Marketing communication } \\
\text { via traditional media }\end{array}$ \\
\hline Open system & Closed system \\
\hline Transparent & Mon-transparent \\
\hline One on one communication & Product oriented \\
\hline User oriented & $\begin{array}{c}\text { The content is created by } \\
\text { professionals }\end{array}$ \\
\hline Users create the content & Polished content \\
\hline Unique content & Payable \\
\hline Basically free & Measuring the effectiveness: \\
reach, frequency \\
participation, user involvement
\end{tabular}

Table 1. Differences between marketing communication media. Source: http://www.hausmanmarketingletter.com/

In addition to these strengths, the Internet usage in interactive communication with consumers has its bad side. Especially, the paradoxical feature of the Internet lies in the possibility that anyone with access to a computer and Internet connection can become a producer of content on the web. Therefore, it is often presented as a chaotic mix of information and misinformation. However, besides publishing poor quality content, social isolation, etc., it exerts its greatest weakness in the consumer privacy protection.

\section{INTERNET AND CUSTOMER PRIVACY PROTECTION}

The sharpest criticism of direct marketing activities, especially to those who use the Internet as a medium, refers to its campaigns that are realized in a very intrusive form, which implies encroachment on customer privacy.

It is fact that the information exchange brings benefits to both sides - customers and companies. However, gathering and storage of information about the existing and potential customers is a prerequisite for personalization and creation of offer in accordance with the customer requirements. An effective direct marketing requires a balance between the benefits of customers and companies.

In practice, companies sometimes collect information without the authorization of the customer. For example, when customer visits a firm's website, he /she could be unwittingly providing that company with information such as his/her IP address, the page that referred him/her to the website and the pages being currently viewed. If the website also utilizes cookies and other tracking devices, companies can gather even more information.

Customers often feel irritated when they believe that they have received a lot of direct mail or information about their private lives without the approval. They can trust that their personal information was leased, sold, borrowed or even stolen.
Due to that, direct sellers must comply with the information in a way that will respect the ethical principles and comply with the customer requirements that their personal information remains confidential. If there is an invasion on customer privacy, the following business motto can be applied: "cheated client = permanently lost client" (Kocić, 2007). Considering that this is the worst result for the company, the process of collecting and using data about consumers must be an important task which should be approached with the highest degree of prudence.

\section{CONCLUSION}

There is no doubt that the Internet represents an essential tool in communicating with consumers in the context of globalization. Because of its advantages over other media, which are discussed in this paper, the Internet has the leading position in the process of interactive communication with clients. However, its supremacy over other media does not exclude the importance of traditional tools.

In other words, mass media do not lose their importance, but they are combined with new forms in order to ensure clarity, consistency, scope and impact of the message. Developing a program of interactive communication is primarily based on the formats and media that enable the transfer of information to the recipient in the fastest, most comprehensive and most effective way.

Synergetic effect provides a higher level of message consistency and interactivity and maximizes end result. Due to that, the Internet, with all its good and bad sides, must be seen as a segment of integrated marketing communications.

\section{REFERENCES}

Chaffey, D., Mayer, R., Johnston, K., \& Chadwick, F. (2000). Internet Marketing. London: Prentice Hall.

Đukić, S. (2007), Integrisanje komunikacionih aktivnosti u funkciji unapređenja poslovne efikasnosti. Ekonomske teme, 1, 9-20.

Hausman Marketing Letter. (2015). Digital Marketing. Retrieved March 12, 2015 from http://www.hausmanmarketingletter. com

Internet Live Stats. (2015). Internet Live Stats. Retrieved March 30, 2015 from http://www.internetlivestats.com.

Jones, A., Malczyk, A., \& Beneke, J. (2011). Internet marketing: A highly practical guide to every aspect of internet marketing. GetSmarter.

Kende, M. (2014). Global Internet Report 2014: Open and Sustainable Access for All. Geneva: Internet Society. Retrieved March 12, 2015 from http://www.internetsociety.org/sites/ default/files/Global_Internet_Report_2014_0.pdf

Kocić, M. (2007), Zaštita privatnosti podataka kao determinanta uspeha direktnog marketinga. Ekonomske teme, 2, 101-110.

Kotler, P. (2000). Marketing management. London: Prentice-Hall.

Pickton, D., \& Broderick, A. (2001). Integrated Marketing Communications. Pearson Education Ltd.

Radivojević, V., \& Krstić, M. (2012). Mediji direktnog marketinga u funkciji unapređenja poslovne konkurentnosti. Poslovna ekonomija. 10(1), 173-198.

Tapp, A. (2005). Principles of direct and database marketing. London: Prentice Hall. 